\section{Value of Anthropometric Measurements in Predicting Difficult Laryngoscopy in Children: A Prospective, Observational Study}

\author{
Çocuklarda Zor Laringoskopinin Öngörüsünde \\ Antropometrik Ölçümlerin Değeri: \\ Prospektif, Gözlemsel Bir Çalışma
}

\author{
Gaye Aydın ${ }^{\oplus}$ \\ Sanem Güntürk ๑ \\ Meltem Çakmak $\odot$ \\ Yücel Karaman $\odot$ \\ Mustafa Onur Öztan ๑ \\ Pervin Sutaş Bozkurt $\odot$ \\ Gizem Cabbaroğlu $\odot$ \\ Rıza Hakan Erbay $\odot$
}

\begin{abstract}
Objective: Ensuring airway security carries the utmost importance in anesthesia. Specific predictive tests or findings for difficult airway are not defined for children under 3 years old. This study is aimed at finding out the value of anthropometric measurements in the prediction of difficult laryngoscopy and intubation in children by comparing them to direct laryngoscopic evaluation of Cormack-Lehane test and intubation evaluation of Intubation Difficulty Scale."

Method: A total of 108 patients (aged 0-3 years), undergoing elective surgery were included in this study. Patients with known syndrome, facial anomaly, Anesthesiologists Physical Status Classification Class >2, and laryngeal mask airway were excluded from the study. Demographic data, head circumference, weight, height measurements, body mass index and percentile values were recorded by a pediatric surgeon in the preoperative period. During laryngoscopy and intubation evaluations were made using Cormack-Lehane Score and Intubation Difficulty Scale and recorded by a blinded resient. All recorded parameters were compared with Cormack-Lehane and Intubation Difficulty Scale scores.

Results: When all parameters were compared with CL Grade I-II-III, IDS scores; a statistically significant difference was found between age and head circumference and CL Grade I, II ( $p<0.05, p<0.05)$. When all parameters were compared in terms of difficult and easy direct laryngoscopy, relations between difficult direct laryngoscopy and male gender and low weight percentile were observed ( $p<0.05)$. Difficult intubation was not found according to Intubation Difficulty Scale.

Conclusion: Anthropometric measurements are not predictive for difficult direct laryngoscopy and difficult intubation in pediatric patients. The potentiality of difficult direct laryngoscopy could be higher in boys than girls and in children with low weight percentile.
\end{abstract}

Keywords: Airway, pediatrics, laryngoscopy, difficult, general anesthesia, measurements

öz

Amaç: Hava yolu güvenliğinin sağlanması anestezide büyük önem taşımaktadır. Üç yaşından küçükler için spesifik zor havayolu ve entübasyon öngörü testleri veya zor hava yolu bulguları tanımlanmamıştır. Bu çalıșma, çocuklarda zor laringoskopi ve entübasyon tahmininde antropometrik ölçümlerin doğrudan laringoskopik görüntülemeyi değerlendiren Cormack-Lehane ve entübasyon değerlendirmesini ölçen "Entübasyon Zorluk Ölçeği" skorlamaları ile karşılaştırılmasını amaçlamaktadır.

Yöntem: Bu çalışmaya elektif cerrahi geçiren toplam 108 hasta (0-3 yaş) dahil edildi. Bilinen sendromu olan hastalar, yüz anomalisi, Anestezistlerin Fiziksel Durum Sınıflandırması 2'nin üzerinde, laringeal maske hava yolu uygulanan hastalar çalışma dışı bırakıldı. Ameliyat öncesi dönemde çocuk cerrahı tarafından demografik veriler, baş çevresi, ağırlık, boy ölçümleri, vücut kitle indeksi ve persentil değerleri kaydedildi. Laringoskopi ve entübasyon sırasında Cormack-Lehane Skoru ve Entübasyon Zorluk Ölçeğine göre parametreler değerlendirildi ve çalışmayı bilmeyen asistan tarafından kaydedildi. Kaydedilen tüm parametreler Cormack-Lehane ve Entübasyon Zorluk Ölçeği skorları ile karşılaştıııldı.

Bulgular: Tüm parametreler CL Derece I-II-III ve Entübasyon Zorluk Ölçeği skorları ile karșılaștırıldığında; yaş ve baş çevresi ile CL Derece I, II arasında istatistiksel olarak anlamlı bir fark bulundu ( $p<0.05, p<0.05)$. Zor ve kolay direkt laringoskopi açısından tüm parametreler karşılaştırıldığında, zor direkt laringoskopik görüntü ile erkek cinsiyet ve düşük ağırlıklı persentil arasında ilişki saptandı (p<0.05). Entübasyon Zorluk Ölçeği skorlarına göre hiçbir olguda zor entübasyona rastlanmadı.

Sonuç: Antropometrik ölçümler pediyatrik hastalarda zor direkt laringoskopi ve zor entübasyon için öngörücü değildir. Zor direk laringoskopinin potansiyeli erkeklerde kızlardan ve düşük ağırlık yüzdelikli çocuklarda daha yüksek olabilir.
Received/Geliş: 29.03 .2020

Accepted/Kabul: 20.04.2020

Published Online/Online Yayın: 31.08.2020

Gaye Aydın

Sağlık Bilimleri Üniversitesi Tepecik Eğitim ve Araştırma Hastanesi, Anesteziyoloji ve Reanimasyon Kliniği,

İmir- Turkey

drgayeaydin@hotmail.com

ORCiD: 0000-0003-1441-9462

S. Güntürk 0000-0001-6656-1140

M. Çakmak 0000-0001-7764-1840

Y. Karaman 0000-0002-4689-712X

G. Cabbaroğlu 0000-0002-9608-475X

Sağlık Bilimleri Üniversitesi Tepecik Eğitim ve Araştırma Hastanesi, Anesteziyoloji ve Reanimasyon Kliniği,

izmir, Türkiye

M.O. Öztan 0000-0003-3696-4090 Katip Celebi Üniversitesi, Tepecik Eğitim ve Araştırma Hastanesi, Çocuk Cerrahisi Kliniği, Izmir, Türkiye

P. Sutaş Bozkurt 0000-0002-2073-826X istanbul Üniversitesi, Cerrahpaşa Tıp Fakültesi, Anesteziyoloji ve Reanimasyon Anabilim Dalı, istanbul, Türkiye

R.H. Erbay 0000-0003-0609-0580 Pamukkale Üniversitesi, Tıp Fakültesi, Anesteziyoloji ve Reanimasyon Anabilim Dall, Denizli, Türkiye

Anahtar kelimeler: Hava yolu, pediatrik, laringoskopi, zor, genel anestezi, ölçümler

(C) Telif hakkı İzmir Dr. Behçet Uz Çocuk Hastalıkları ve Cerrahisi Eğitim ve Araştırma Hastanesi'ne aittir. Logos Tıp Yayıncılık tarafindan yayınlanmaktadır. Bu dergide yayınlanan bütün makaleler Creative Commons Attf-GayriTicari 4.0 Uluslararası Lisansı ile lisanslanmıştır.

(c) Copyright İzmir Dr. Behçet Uz Children's Hospital. This journal published by Logos Medical Publishing.

Licenced by Creative Commons Attribution-NonCommercial 4.0 International (CC BY) 


\section{INTRODUCTION}

Airway safety in anesthesia is important in pediatric patients as well as in adult patients. However, predicting the difficult airway in children may be more problematic than adults. Difficult airway prediction tests specific to children are few and difficult airway prediction tests used in adults in the clinical routine are difficult to apply to children. For example, Mallampati Score can be used in patients 4 years and older because it is a process that requires cooperation. Difficult airway prediction can be made with morphometric, functional and anatomical determinants in pediatric patients under 3 years of age. Limited head extension, small mandibular space, increased size of tongue and craniofacial dysmorphism can be predictive findings for difficult airway in pediatric cases ${ }^{(1,2)}$. Moreover, congenital anomalies can be a predictive for difficult airway ${ }^{(2)}$. However, scarce data are available on the incidence of difficult intubation and difficult laryngoscopy in pediatric patients according to each age range. According to the data of American Society of Anesthesiologists and Perioperative Cardiac Arrest Registry, pediatric airway management incidents have been reported to result in brain damage, cardiac arrest and death ${ }^{(1,2)}$. For this reason, specific measures and predictive tests related to difficult intubation are very important in children. However, there are not any defined predictive tests concerning difficult intubation and direct laryngoscopy according to the age of the pediatric patients. Difficult Airway Society-Associations of Pediatric Anesthesiologists, Polish Society of Anaesthesiology and Intensive Therapy and The All India Difficult Airway Association (AIDAA) have published guidelines on pediatric difficult airways ${ }^{(3-5)}$.

Children with ASA Class III and IV (American Society of Anesthesiologists III and IV) physical status, Mallampati scores III and IV, low body mass index, those undergoing cardiac surgery, maxillofacial surgery, children during their first year of life and Syndromal children are risk factors for difficult pediatric laryngoscopy. In children undergoing cardiac surgery, difficult laryngoscopy is twice as frequent as when compared to the average for all children $(1,2,2,6)$.
Anthropometric measurements of height, weight and head circumference and percentile curves related to these parameters vary according to the age of pediatric patients and these measurements are used to determine growth and development in children ${ }^{(7)}$. In this study the relation of anthropometric measurements with the direct laryngoscopic view test (Cormack-Lehane test $(\mathrm{CL})$ ) and difficult intubation test (The Intubation Difficulty Scale (IDS)) scores were evaluated. Our major target was to find out the value of these parameters as predictive tests for difficult direct laryngoscopy and difficult intubation in pediatric patients aged $0-3$ years.

\section{MATERIAL and METHODS}

After obtaining Local Ethics Committee approval for the study (Ethical approval for this study (Izmir Tepecik Education and Research Hospital Ethical Committee no: 3/3) was provided by the Ethical Committee Tepecik Education and Research Hospital, Izmir, Turkey (Chairperson: Prof. Dr. Sukran Kose) on June 25,2014$)$ and written informed consent was obtained from the parents of each child. Patients with known syndrome, facial anomaly, Anesthesiologists Physical Status Classification Grade above 2 and laryngeal mask airway were excluded from the study. This prospective study has an observational design. A total of 108 patients; aged 0-3 years with American Society of Anesthesiologists Physical Status Classification Class 1, undergoing elective surgery and patients programmead to be intubated were included in this study. This study was planned for a duration of one year, due to insufficient number of patients, study lasted for two years between July 11, 2014, and July 11, 2016. Percentile curves were determined between 0-36 months in Turkish children. Mallampati classification can be applicable as a predictive test for difficult laryngoscopy in children aged $\geq 4$ years. Therefore, we included patients aged 0-3 years. Demographic data, head circumference, weight, height measurements, body mass index and percentile values were recorded by a pediatric surgeon who was unaware about the study in the preoperative period. Head circumfe- 
rences were taken at the level above eye brows and ears. Pediatric surgeon weighed undressed children without diapers on an electronic scale $(0-20 \mathrm{~kg})$. Children had their height measured using a portable infantometer $(0-100 \mathrm{~cm})$ while the child was in supine position. BMI was calculated as $\mathrm{kg} / \mathrm{m}^{2}$. Intravenous cannula (24 gauge) was placed in the ward and $0.9 \%$ sodium chloride infusion was initiated in the operating room. All cases were monitored by electrocardiograms, noninvasive blood pressure, and pulse oximetry measurements. Anesthesia induction was performed by intravenous administration of thiopental $\left(5 \mathrm{mg}^{\mathrm{kg}}{ }^{-1}\right)$ and fentanyl $\left(1 \mu \mathrm{g} \cdot \mathrm{kg}^{-1}\right)$. Following adequate mask ventilation, rocuronium $\left(0.6 \mathrm{mg} \cdot \mathrm{kg}^{-1}\right)$ was administered intravenously for muscle relaxation. Following mask ventilation for 2 min until the onset of neuromuscular block laryngoscopy was performed by the same anesthesia resident at $3^{\text {rd }}$ year of residency programme. During laryngoscopy ageadapted Macintosh blades were used in all cases. Intubations were performed using sterile, single-use, uncuffed, age-appropriate internal diameter, Portex brand endotracheal tubes. Third attempt at intubation or use of endotracheal tube stylet were considered as difficult intubation. All cases were intubated at first or second attempt. Anesthesia was maintained with an age-appropriate $2-3 \%$ sevoflurane in a 1:1 oxygen/air mixture administered at rate of $2 \mathrm{~L}$. min1. A blinded resident evaluated CL grade, IDS score and recorded the scoring ${ }^{(8,9)}$ (Table 1, Table 2). $C L$ score and IDS score were used to evaluate difficult laryngoscopy and difficult intubation, respectively. CL Grade I and II were evaluated as easy direct laryngoscopy and CL Grade III and IV as difficult direct laryngoscopy. IDS Score $\leq 5$ was evaluated as easy intubation. Also; percentiles below $50 \%$ defined as

Table 1. According CL classification ${ }^{(8)}$.

\begin{tabular}{ll}
\hline CL Grade & Anatomical view \\
\hline Grade 1 & Glottis fully exposed \\
Grade 2 & Glottis partially exposed with anterior \\
Grade 3 & commissure not seen \\
Grade 4 & Only epiglottis seen \\
& Epiglottis not seen \\
\hline
\end{tabular}

$C L=$ Cormack-Lehane low percentile and patients are grouped as low and normal in order to perform the statistical analysis.

Table 2. Intubation difficulty scale score (IDS) ${ }^{(9)}$.

\begin{tabular}{|c|c|}
\hline \multicolumn{2}{|c|}{ Intubation Difficulty Scale } \\
\hline Parameter & Score \\
\hline Number of Attempts>1 & N1 \\
\hline Number of Operators $>1$ & $\mathrm{~N} 2$ \\
\hline Number of alternative techniques & N3 \\
\hline Cormach Grade-1 & N4 \\
\hline \multicolumn{2}{|l|}{ Lifting force requered } \\
\hline Normal & N5 $=0$ \\
\hline Increased & N5=1 \\
\hline \multicolumn{2}{|l|}{ Laryngeal Pressure } \\
\hline Not applied & $N 6=0$ \\
\hline Applied & $N 6=1$ \\
\hline \multicolumn{2}{|l|}{ Vocal cord mobility } \\
\hline Abduction & $N 7=0$ \\
\hline $\begin{array}{l}\text { Adduction } \\
\end{array}$ & $N 7=1$ \\
\hline TOTAL: IDS=SUM OF SCORES & N1-N7 \\
\hline IDS Score & Degree of difficulty \\
\hline 0 & Easy \\
\hline $0<1 D S \leq 5$ & Slight Difficulty \\
\hline $5<$ IDS & Modereate to major difficulty \\
\hline IDS $=\infty$ & Impossible Intubation \\
\hline \multicolumn{2}{|l|}{ Rules for Calculating IDS Score } \\
\hline \multicolumn{2}{|c|}{ N1 Every additional attempt adds $1 \mathrm{pt}$. } \\
\hline \multicolumn{2}{|c|}{ N2 Each additional operator adds $1 \mathrm{pt}$. } \\
\hline \multicolumn{2}{|c|}{$\begin{array}{l}\text { Each alternative technique adds } 1 \text { point. Repositioning of } \\
\text { the patient, change of materials (blade, ET tube, additing of } \\
\text { a stylette), change in approache (nasotracheal/orotracheal) } \\
\text { or use of another technique (fiberoscopy, intubation tro- } \\
\text { ught a laryngeal mask) }\end{array}$} \\
\hline \multicolumn{2}{|c|}{$\begin{array}{l}\text { Apply Cormack grade for 1st oral attempt. For successful } \\
\text { blind intubation N4=0 }\end{array}$} \\
\hline \multicolumn{2}{|c|}{ N6 Sellick's maneuver adds no points. } \\
\hline \multicolumn{2}{|c|}{$\begin{array}{l}\text { Impossible intubation=IDS takes the value attained before aban- } \\
\text { donment of intubation attemps. }\end{array}$} \\
\hline
\end{tabular}

\section{Statistical analysis}

Descriptive statistics were used to describe continuous variables (mean, standard deviation, minimum, median, maximum). The Kruskal-Wallis test was used to compare the continuous variables of more than two groups that did not meet the normal distribution. Comparisons of and normally distributed two independent continuous variables were made using Student's $t$ test and Mann-Whitney $U$ test was used in order to compare two independent variables with non-normal distribution. Chi-square 
test or Fisher's exact tests were used to examine the relationship between categorical variables where appropriate. Level of statistical significance was determined as 0.05 . Analyzes were performed using the Med. Calc. Statistical Software Version 12.7.7 program (Medcalc Software buba,Ostend, Belgium; http://www.medcalc.org; 2013).

\section{RESULTS}

A total of 108 patients between 0-3 years of age were included in this study. The numbers of boys $(n=57,52.8 \%)$ and girls ( $n=51,47.2 \%)$ were similar. Mean age of the patients was $12.8 \pm 10.9$ months (95\% Confidence Interval (Cl) 10.71-14.89), mean weight was $8.4 \pm 3.8 \mathrm{~kg}$ (95\% Cl:7.72-9.24), mean height was $71.33 \pm 15 \mathrm{~cm}$ (95\% Cl: 68.41-74.40), mean head circumference was $43.3 \pm 5 \mathrm{~cm}(95 \% \mathrm{Cl}$ : 42.20-44.26) and mean BMI was $15.6 \pm 3 \mathrm{~kg} \mathrm{~m}^{-2}(95 \%$ $\mathrm{Cl}: 15.08-16.20)$.

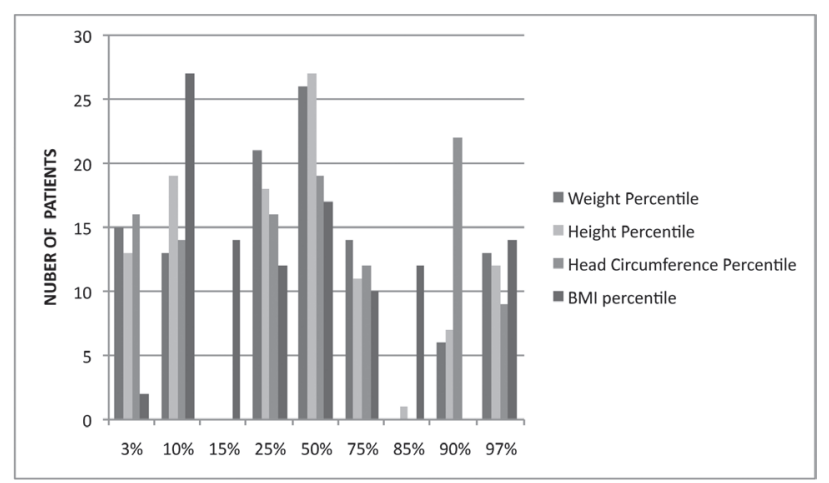

Figure 1. Distribution of weight, height, head circumference, and $B M I$ percentiles. $Y$ axis is number of patients.

Tablo 3. Comparison of all parameters with $\mathrm{CL}$ grading.

\begin{tabular}{|c|c|c|c|c|c|c|c|}
\hline \multirow[b]{2}{*}{ Parameters } & \multirow[b]{2}{*}{$\mathrm{CL}$ grading } & \multirow[b]{2}{*}{$\mathbf{n}$} & \multirow[b]{2}{*}{$\begin{array}{l}\text { Mean } \pm S D \\
\text { Med [IQR] }\end{array}$} & \multirow[b]{2}{*}{ OR } & \multicolumn{2}{|c|}{$\% 95 \mathrm{Cl}$} & \multirow[b]{2}{*}{$\mathbf{p}$} \\
\hline & & & & & $\begin{array}{l}\text { Lower } \\
\text { Bound }\end{array}$ & $\begin{array}{l}\text { Upper } \\
\text { Bound }\end{array}$ & \\
\hline \multirow[t]{3}{*}{ Age (month) } & 1 & 47 & $\begin{array}{l}14.8 \pm 9.6 \\
13[1-36]\end{array}$ & 0.78 & 11.94 & 17.58 & $0.045^{*}$ \\
\hline & II & 42 & $\begin{array}{c}11 \pm 12.8 \\
4.75[1-36]\end{array}$ & 0.63 & 7.06 & 15.03 & \\
\hline & III & 19 & $\begin{array}{c}11.8 \pm 9.3 \\
9[1-29]\end{array}$ & 0.20 & 7.36 & 16.31 & \\
\hline \multirow[t]{3}{*}{ Weight (kg) } & I & 47 & $\begin{array}{c}9.1 \pm 3 \\
10[2.8-15]\end{array}$ & 0.78 & 8.23 & 10.03 & 0.232 \\
\hline & II & 42 & $\begin{array}{c}7.8 \pm 4.9 \\
6.5[2,5-20]\end{array}$ & 0.63 & 6.33 & 9.38 & \\
\hline & III & 19 & $\begin{array}{c}8.3 \pm 3.6 \\
9[2.4-16]\end{array}$ & 0.20 & 6.5 & 10 & \\
\hline \multirow[t]{3}{*}{ Height $(\mathrm{cm})$} & I & 47 & $\begin{array}{c}74.9 \pm 13.6 \\
77[47-100]\end{array}$ & 0.78 & 70.91 & 78.89 & $0.08 *$ \\
\hline & II & 42 & $\begin{array}{c}67.3 \pm 17.9 \\
63[45-108]\end{array}$ & 0.63 & 61.71 & 72.9 & \\
\hline & III & 19 & $\begin{array}{l}71.8 \pm 13.7 \\
71[47-96]\end{array}$ & 0.20 & 65.22 & 78.76 & \\
\hline \multirow[t]{3}{*}{ Head circumference $(\mathrm{cm})$} & I & 47 & $\begin{array}{c}44.8 \pm 4.7 \\
46[32.5-52]\end{array}$ & 0.78 & 43.37 & 46.16 & 0.017 \\
\hline & II & 42 & $\begin{array}{c}41.4 \pm 5.9 \\
40.5[32-54]\end{array}$ & 0.63 & 36.56 & 43.24 & \\
\hline & III & 19 & $\begin{array}{c}43.7 \pm 4.6 \\
45[33-50]\end{array}$ & 0.20 & 41.25 & 45.69 & \\
\hline \multirow[t]{3}{*}{ BMI (kg.m-2) } & 1 & 47 & $\begin{array}{c}15.9 \pm 2.8 \\
15[11.8-22,4]\end{array}$ & 0.78 & 15.04 & 16.69 & 0.806 \\
\hline & II & 42 & $\begin{array}{c}15.6 \pm 3.1 \\
15.1[10.2-25,9]\end{array}$ & 0.63 & 14.61 & 16.54 & \\
\hline & III & 19 & $\begin{array}{c}15.2 \pm 3.1 \\
15.2[10.7-24.4]\end{array}$ & 0.20 & 13.74 & 16.2 & \\
\hline
\end{tabular}

*Kruskal-Wallis $p<0.05, C L=$ Cormack-Lehane, $S D=S t a n d a r t$ Deviation, Med=Median, IQR=Interquartile range, OR=odds ratio, $C l=C o n f i d e n c e$ Interval 
Table 4. Comparison of all parameters with IDS scores.

\begin{tabular}{|c|c|c|c|c|c|c|c|}
\hline \multirow[b]{2}{*}{ Parameters } & \multirow[b]{2}{*}{ IDS Score } & \multirow[b]{2}{*}{$\mathbf{n}$} & \multirow[b]{2}{*}{$\begin{array}{l}\text { Mean士SD } \\
\text { Med [IQR] }\end{array}$} & \multirow[b]{2}{*}{ OR } & \multicolumn{2}{|c|}{$\% 95 \mathrm{Cl}$} & \multirow[b]{2}{*}{ p } \\
\hline & & & & & $\begin{array}{l}\text { Lower } \\
\text { Bound }\end{array}$ & $\begin{array}{l}\text { Upper } \\
\text { Bound }\end{array}$ & \\
\hline \multirow[t]{4}{*}{ Age (month) } & 0 & 89 & $\begin{array}{c}13.01 \pm 11.30 \\
11.5[1-36]\end{array}$ & 0.82 & 10.63 & 15.39 & 0.67 \\
\hline & $0<I D S \leq 5$ & 19 & $\begin{array}{c}11.84 \pm 9.28 \\
9[1-29]\end{array}$ & 0.18 & 7.36 & 16.31 & \\
\hline & $5<$ IDS & 0 & - & - & - & - & \\
\hline & $I D S=\infty$ & 0 & - & - & - & - & \\
\hline \multirow[t]{4}{*}{ Weight (kg) } & 0 & 89 & $\begin{array}{l}8.53 \pm 4.04 \\
9[2.5-20]\end{array}$ & 0.82 & 7.67 & 9.38 & 0.85 \\
\hline & $0<1 D S \leq 5$ & 19 & $\begin{array}{l}8.28 \pm 3.59 \\
9[2.36-16]\end{array}$ & 0.18 & 6.55 & 10.01 & \\
\hline & $5<$ IDS & 0 & - & - & - & - & \\
\hline & IDS $=\infty$ & 0 & - & - & - & - & \\
\hline \multirow[t]{4}{*}{ Height $(\mathrm{cm})$} & 0 & 89 & $\begin{array}{l}71.32 \pm 16.15 \\
72[45-108]\end{array}$ & 0.82 & 67.91 & 74.72 & 0.89 \\
\hline & $0<1 D S \leq 5$ & 19 & $\begin{array}{c}71.84 \pm 13.73 \\
71[47-96]\end{array}$ & 0.18 & 65.22 & 78.46 & \\
\hline & $5<$ IDS & 0 & - & - & - & - & \\
\hline & $I D S=\infty$ & 0 & - & - & - & - & \\
\hline \multirow[t]{4}{*}{ Head circumference $(\mathrm{cm})$} & 0 & 89 & $\begin{array}{l}43.18 \pm 5.56 \\
45[32-54]\end{array}$ & 0.82 & 42 & 44.35 & 0.89 \\
\hline & $0<1 D S \leq 5$ & 19 & $\begin{array}{c}43.47 \pm 4.61 \\
45[33-50]\end{array}$ & 0.18 & 41.25 & 45.69 & \\
\hline & $5<$ IDS & 0 & - & - & - & - & \\
\hline & IDS $=\infty$ & 0 & - & - & - & - & \\
\hline \multirow[t]{4}{*}{ BMI (kg. m²) } & 0 & 89 & $\begin{array}{c}15.73 \pm 2.93 \\
15[10.24-25.97]\end{array}$ & 0.82 & 15.11 & 16.35 & 0.56 \\
\hline & $0<$ IDS $\leq 5$ & 19 & $\begin{array}{c}15.23 \pm 3.1 \\
15.2[10.71-24.48]\end{array}$ & 0.18 & 13.74 & 16.73 & \\
\hline & $5<$ IDS & 0 & - & - & - & - & \\
\hline & $I D S=\infty$ & 0 & - & - & - & - & \\
\hline
\end{tabular}

Kruskal-Wallis $p<0.05, I D S=$ Intubation Difficulty Scale, SD=Standart Deviation, Med=Median, IQR=Interquartile Range, OR=odds ratio, $\mathrm{Cl}=$ Confidencelnterval

Table 5. Incidence of easy and difficult laryngoscopy and gender and percentile characteristics of patients and statistic alanalysis.

\begin{tabular}{|c|c|c|c|c|c|c|c|}
\hline \multirow[b]{2}{*}{ Parameters } & & \multirow[b]{2}{*}{$\begin{array}{l}\text { Difficult laryngoscopy } \\
\text { (n) }\end{array}$} & \multirow[b]{2}{*}{$\begin{array}{l}\text { Easy laryngoscopy } \\
\text { (n) }\end{array}$} & \multirow[b]{2}{*}{ OR } & \multicolumn{2}{|c|}{$\% 95 \mathrm{Cl}$} & \multirow[b]{2}{*}{ p } \\
\hline & & & & & $\begin{array}{l}\text { Lower } \\
\text { Bound }\end{array}$ & $\begin{array}{l}\text { Upper } \\
\text { Bound }\end{array}$ & \\
\hline \multirow[t]{2}{*}{ Gender } & Boys & 15 & 42 & 4.1 & 1.29 & 13.64 & $0.01 *$ \\
\hline & Girls & 4 & 47 & & & & \\
\hline \multirow[t]{2}{*}{ Weight percentile } & $3-49 \%$ & 14 & 36 & 4.12 & 1.36 & 12.45 & $0.0086^{*}$ \\
\hline & $50-97 \%$ & 5 & 53 & & & & \\
\hline \multirow[t]{2}{*}{ Height percentile } & $3-49 \%$ & 10 & 35 & 1.71 & 0.63 & 4.64 & 0.2 \\
\hline & $50-97 \%$ & 9 & 54 & & & & \\
\hline \multirow[t]{2}{*}{ Head Circumference percentile } & $3-49 \%$ & 12 & 37 & 2.40 & 0.86 & 6.70 & 0.07 \\
\hline & $50-97 \%$ & 7 & 52 & & & & \\
\hline \multirow[t]{2}{*}{ BMI percentile } & $3-49 \%$ & 13 & 42 & 2.42 & 0.84 & 6.95 & 0.07 \\
\hline & $50-97 \%$ & 6 & 47 & & & & \\
\hline
\end{tabular}

*Chi-Square $p>0.05$ (withWoolfmean), OR=odds ratio, $C l=$ Confidence Interval, $B M I=B o d y$ mass index

The body weight, height, head circumference, and body mass index of the Turkish children ${ }^{(7)}$ were determined according to the reference values as percentiles of the cases were $3 \%, 10 \%, 25 \%, 50 \%$, 
75\%, 90\%, 97\%, respectively (Figure 1). Eighty-nine cases out of 108 were CL Grade I-II, and 19 cases were $\mathrm{CL}$ Grade III. No cases of CL Grade IV were encountered. IDS score was determined at all cases as 5 or less. According to IDS score difficult intubation (moderate to major difficulty and impossible intubation) was not found in any of the cases. Eightynine cases out of 108 had an IDS score of 0 (easy), and 19 cases had IDS scores between 0 , and $\leq 5$ (slight difficulty).

When all parameters were compared based on $\mathrm{CL}$ Grades I-II-III and IDS scores; a statistically significant difference was found between age and head circumference and $C L$ Grades I and II $(p<0.05, p<0.05)$ (Table 3,4). Any statistically significant differences were not found regarding other parameters. When all parameters were compared in terms of difficult and easy direct laryngoscopy, correlations between difficult direct laryngoscopy and male gender and low weight percentile were observed $(p<0.05)$ (Table 5).

\section{DISCUSSION}

Our initial aim was to compare direct laryngoscopic test Cormack-Lehane and difficult intubation test The Intubation Difficulty Scale with demographic data and percentile curves in pediatric patients aged 0-3 years. Secondary aim was to determine predictions of difficult airway with these parameters in pediatric patients aged 0-3-year-old children.

When distribution of the measurements made on 108 cases, other than male gender and low weight percentile there was no statistical significance in terms of efficacy as difficult laryngoscopy and difficult intubation predictive tests. The incidence of difficult intubation is significantly lower in pediatric patients than in adults. However, the pediatric anesthesiologist should be prepared for the anticipated, unexpected and questionable difficult airway management. The difficult airway predictive tests used in adults may not be useful for pediatric patients. Difficult airway (difficult mask, difficult intubation or both of them) is usually associated with the presence of syndromes in pediatric cases and inexperience of attending anesthesiologist. As a difficult intubati- on prediction test, the Mallampati Score can be used in children aged 4 years and above. However, since cooperations can not be established in younger pediatric cases, Mallampati test is not practical as a predictive test ${ }^{(10)}$. Physical examination findings such as short mandible, limitation of mouth opening, ear deformity, facial anomaly, and cleft palate may be helpful in predicting difficult intubation during pediatric cases ${ }^{(10,11)}$.

The incidence of grade III-IV direct laryngoscopic views in pediatric cases vary between $1.35 \%$ and $10.4 \%$, depending on the literature ${ }^{(1,12-15)}$. In the studies of Hendrich et al. ${ }^{(1,2)}$ the incidence of difficult direct laryngoscopy in children had been reported as $1.35 \%, 3.5 \%$, respectively. These studies are retrospective and direct laryngoscopy performed is not standardized. Graciano et al. ${ }^{(12)}$ reported a $9 \%$ incidence of difficult intubation in pediatric intensive care unit. In this study, difficult intubation had defined as direct laryngoscopy, which failed or required more than two laryngoscopy attempts by fellow/ attending physician. Cormach Lehane score was reported to be high when difficult intubation was detected. But this prospective, observational study had been conducted across 15 academic pediatric ICUs in North America and intubation had been performed by different academicians. Aggarwal et al. ${ }^{(14)}$ had found incidence of difficult intubation as more than $40 \%$ (Intubation Difficulty Score mild 40\%, major $2 \%$ ) while incidence of difficult direct laryngoscopy was 3 percent. In our study there was no intubation difficulty in $82.4 \%$ of the cases. Rest of the cases (17.6\%) in our study showed mild difficulty $(0<\mid D S>5)$ on the other hand major difficulty (IDS $>5$ ) was not found.

Long et al. ${ }^{(13)}$, Aggarwal et al. ${ }^{(14)}$, Inal et al. (15) had found incidence of difficult direct laryngoscopy in pediatric patients as $7 \%, 3 \%$, and $10.4 \%$, respectively. Age ranges of these different study populations were 10 months-11 years, 1 - 5 years, and 5-11 years, respectively ${ }^{(13-15)}$. It is quite obvious that the incidence of difficult direct laryngoscopy varies. In these studies number of patients, ages of children and physician's experience on direct laryngoscopy were diversified The incidence of difficult 
intubation was found to be higher in children under 1 year of age than in other pediatric cases ${ }^{(1,2,12,16,17)}$. The incidence rates of difficult direct laryngoscopy in the studies were $3.2 \%, 5 \%, 2.5 \%, 6.6 \%, 10.7 \%$ and $16.4 \%$, respectively ${ }^{(1,2,16,17)}$. The age of the children and the experience of the physicians are important in determination of the incidence of difficult direct laryngoscopy. We think that in our study the incidence of difficult laryngoscopy is high due to the low experience of the practitioner and the large number of cases under 1 year of age.

Mansano et al. ${ }^{(16)}$ investigated predictive tests in children under 12 years of age in 3 age groups. They found that the frontal plane-to-chin distance-toweight ratio can be used as a prediction test for difficult laryngoscopy in age group of 0-6 months. In the same study difficult direct laryngoscopy had been observed in 11 males and 4 females, however gender and difficult laryngoscopy were not compared.

Heinrich et al. (1) found statistically significant difference between low BMI and difficult laryngoscopy. They reported that the probability of difficult laryngoscopy was higher in patients with ASA Class III-IV (Anesthesiologists Physical Status Classification III-IV) but they had not find any correlation between gender and difficult laryngoscopy. Similar to our findings Heinrich et al. ${ }^{(2)}$ reported that the incidence of difficult laryngoscopy was higher in boys. In the same study, they emphasized that the rate of difficult laryngoscopy increased in children with $\mathrm{BMI}<3 \%$ and $>97 \%$. Nafiu et al. ${ }^{(18)}$ found that high $\mathrm{BMI}$, and obesity had been correlated with difficult laryngoscopy. In our study there was no statistically significant difference between direct laryngoscopy and BMI. Whereas difficult direct laryngoscopy was significantly higher in patients with low weight percentile.

Correlation between age and $\mathrm{CL}$ grading in pediatric cases was noted in the study of Asggarwal et al. (14), and it was emphasized that incidence rates for $\mathrm{CL}$ Grade I increased and CL Grade II-III decreased as age increased.

In studies investigating age, height, body mass, difficulty of intubation and classification of
Mallampati in 4-8 year-old children, any correlation was not noted between observed parameters and difficult laryngoscopy ${ }^{(19)}$.

Kandemir et al. ${ }^{(20)}$ reported that the probability of difficult intubation increases as the measurement of the head circumference increases in adult cases. But there is no study on the correlation between head circumference and difficult laryngoscopy in pediatric cases.

In conclusion, difficult laryngoscopy was not encountered in children aging 0-3 years, and any predictive test for difficult intubation was not detected. Many studies have reported data on age, body weight, and height, anthropometric measurements of the patients, however these varriables have not been evaluated for correlation with difficult laryngoscopy or difficult intubation. In literatüre search there were no studies evaluating the correlation between difficult laryngoscopy/difficult intubation, percentiles and anthropometric measurements.

Anthropometric measurements and head circumference, height and BMI percentiles do not provide any advantage in prediction of difficult laryngoscopy. Anesthesiologists should be aware that low weight percentile and male gender have higher risks for difficult laryngoscopy. We think that more precise results will be obtained by increasing the number of cases.

\section{Acknowledgements relating to this article}

Assistance with the Study: The authors thank Prof. Dr.Mehmet Orman (Department of Biostatistical, Ege University, Medical Faculty, Izmir, Turkey) for statistical analysis.

Presentation: This report was previously submitted in part as an oral presentation at the 3rd Conference Cadaveric Dissection Course Hands-on Workshop Compromised/DifficultAirway \& Laryngotracheal Stenosis. Endorsed by European Airway Management Society and Society In Europe For Simulation Applied To Medicine, Izmir-Turkey, November 24-25, 2017"

Trial Registration: "Trial Registration:Clinicaltrials. gov identifier:NCT00405977" 
Ethics Committee Approval: T. C. Ministry of Health, Public Hospitals Authority Turkey Izmir North Public Hospital Association General Secretariat of the Council Tepecik Training and Research Hospital was approved by the local meat (25.06.2014 / 3).

\section{Conflict of Interest: None.}

Funding: None.

Informed Consent: Obtained.

\section{REFERENCES}

1. Heinrich S, Birkholz T, Ihmsen H, Irouschek A, Ackermann A, Schmidt J. Incidence and predictors of difficult laryngoscopy in 11.219 pediatric anesthesia procedures. Pediatr Anesth. 2012; 22:729-36. https://doi.org/10.1111/j.1460-9592.2012.03813.x

2. Heinrich $S$, Birkholz $T$, Ihmsen $H$, et al. Incidence and predictors of poor laryngoscopic view in children undergoing pediatric cardiac surgery. J Cardiothorac Vasc Anesth. 2013;27:516-21. https://doi.org/10.1053/j.jvca.2012.08.019

3. www.das.uk.com/guidelines/paediatric-difficult-airwayguidelines in 2015.

4. Walas, W, Aleksandrowicz, D, Borszewska-Kornacka, M, et al. A. Unanticipated difficult airway management in childrenthe consensus statement of the Paediatric Anaesthesiology and Intensive Care Section and the Airway Management Section of the Polish Society of Anaesthesiology and Intensive Therapy and the Polish So. Anaesthesiology intensive therapy, 2017; 49(5): 336-49. https://doi.org/10.5603/AIT.2017.0079

5. Pawar DK, Doctor JR, Raveendra US, et al. All India Difficult Airway Association 2016 guidelines for the management of unanticipated difficult tracheal intubation in paediatrics. Indian J Anaesth. 2016;60(12):906-14. https://doi.org/10.4103/0019-5049.195483

6. Streiff A, Chimhundu-Sithole T, Evans F. Approach to the Paediatric Difficult Airway in a High-Versus Low-Resource Setting: A Comparison of Algorithms and Difficult-Airway Trolleys (www.wfsahq.org/resources/anaesthesia-tutorialof-the-week. ATOTW 399-published 5 March 2019).

7. Neyzi O, Gunoz H, Furman A, Bundak, R, Gokcay G, Darendeliler F. Weight, height, head circumference and body mass index references for Turkish children. Çocuk Sağlığı ve Hastalıkları Dergisi. 2008;51:1-14.

8. Krage R, Van Rijn C, Van Groeningen D, Loer SA, Schwarte LA, Schober P. Cormack-Lehane classification revisited. Br J Anaesth. 2010;105:220-7. https://doi.org/10.1093/bja/aeq136

9. Adnet F1, Borron SW, Racine SX, et al. The intubation difficulty scale (IDS): proposal and evaluation of a new score characterizing the complexity of endotracheal intubation. Anesthesiology. 1997;87(6):1290-7. https://doi.org/10.1097/00000542-199712000-00005

10. Karsli C. Managing the challenging pediatric airway: Continuing Professional Development. Can J Anaesth. 2015;62:1000-16. https://doi.org/10.1007/s12630-015-0423-y

11. Harless J, Ramaiah R, Bhananker SM. Pediatric airway management. Int J Crit IIIn Inj Sci. 2014;4:65-70. https://doi.org/10.4103/2229-5151.128015

12. Graciano AL, Tamburro R, Thompson AE, Fiadjoe J, Nadkarni VM, Nishisaki A. Incidence and associated factors of difficult tracheal intubations in pediatric ICUs: a report from National Emergency Airway Registry for Children: NEAR4KIDS. Intensive Care Med. 2014;40:1659-69. https://doi.org/10.1007/s00134-014-3407-4

13. Long E, Sabato S, Babl FE. Endotracheal intubation in the pediatric emergency department. Pediatr Anesth. 2014;24:1204-11. https://doi.org/10.1111/pan.12490

14. Aggarwal A, Sharma KR, Verma UC. Evaluation of difficult Airway predictors in pediatric population as a clinical investigation. J Anesth Clin Res 2012;3:1-5. https://doi.org/10.4172/2155-6148.1000256

15. Inal MT, Memiş D, Sahin SH, Gunday, I. Comparison of different tests to determine difficult intubation in pediatric patients. Rev Bras Anestesiol. 2014;64:391-4. https://doi.org/10.1016/j.bjan.2014.02.001

16. Mansano AM, Módolo, NS, Silva LM, et al. Bedside tests to predict laryngoscopic difficulty in pediatric patients. Inter J Pediatr Otorhinolaryngol. 2016;83:63-8. https://doi.org/10.1016/j.ijporl.2016.01.031

17. Mirghassemi A, Soltani AE, Abtahi M. Evaluation of laryngoscopic views and related influencing factors in a pediatric population. Pediatr Anesth. 2011;21:663-7. https://doi.org/10.1111/j.1460-9592.2011.03555.x

18. Nafiu OO, Reynolds PI, Bamgbade OA, Tremper KK, Welch K, Kasa-Vubu JZ. Childhood body mass index and perioperative complications. Pediatr Anesth., 2007;17:426-30. https://doi.org/10.1111/j.1460-9592.2006.02140.x

19. Santos AP, Mathias LA, Gozzani JL, Watanabe M. Difficult intubation in children: applicability of the Mallampati index. Rev Bras Anestesiol. 2011;61:159-62. https://doi.org/10.1590/\$0034-70942011000200005

20. Kandemir T, Savlı S, Ünver S, Kandemir E. Sensitivity of the Combination of Mallampati Scores with Anthropometric Measurements and the Presence of Malignancy to Predict Difficult Intubation. Turk J Anaesthesiol Reanim. 2015;43:712

https://doi.org/10.5152/TJAR.2014.24993 